\title{
Modeling and Simulation of E-commerce Steel Logistics System Based on Arena
}

\author{
Xin Li, Kai-Ling Pan \\ School of Management, Wuhan University of Science and Technology, Wuhan, China \\ E-mail: 353930944@qq.com,pank10122@qq.com
}

\begin{abstract}
In this paper, it will compare the system of traditional steel logistics with e-commerce steel logistics system, and find the existing problems and the reasons in current ecommerce steel logistics system .The logistics system simulation model has been established based on Arena simulation software. Using queuing theory to set parameters reasonably. Eventually, giving the performance analysis of simulation results to generate optimized recommendations as well as the corresponding conclusions.
\end{abstract}

Keywords-component; Steel logistics system; E-commerce; Arena simulation software; Performance analysis

\section{INTRODUCTION}

In recent years, the overcapacity problem of Chinese steel industry is serious, the market is saturated with steel products, the steel output showed a declining trend to a certain extent, the continuity of the situation the main business losses is serious, so many steel enterprises used advance the development of maintenance plans to reduce the risks and costs. And also with the influence of the restructuring of the steel industry under internationalize great environment, There are a lot of problems can be found in operation of the traditional steel logistics system, such as the hierarchical information transmission is inefficient, the resource is used unreasonable, the upper enterprises can not know timely about the end-user demand, which is become the part of the iron and steel industry in urgent need to be solved. Although the whole steel industry is in recession ,the model of the steel enterprises operation on the E-commerce platform are keeping good growth momentum, many enterprises believe that this is a good chance for transition and upgrading of steel enterprises.

Steel logistics system is a complex operation system with nonlinear structure, it is difficult to establish a mathematical model of conventional quantitative analysis [1], Therefore, this paper focus on the process of logistics system operation analysis, Comparing with the traditional mode of steel logistics performances, and transform the real process of logistics distribution to a simulation model, using Arena software to simulate the operation process of the logistics system [2], Combined with the relevant theoretical method to set the parameters for each process, and provide a theoretical basis for the traditional steel enterprise achieving network management $[3,4]$.

\section{PROBLEM DESCRIPTION}

In the traditional mode of steel logistics, the steel enterprises may be manufacturers to product steel products, there are dealers to directly provide steel products, and they also can act as distributors and retailers to sell part of the goods. This model is not very clear division of labor management, steel trade business which is at the down string of the supply chain are complex and changeable[5],inefficiency of delivering goods, and the distribution channels are the most complicated. In order to change the status quo of this operation, the e-commerce logistics platform has been established, using this mode hope to solve the problem of scattered layout and unreasonable distribution of resources existing in traditional mode of steel logistics.

\section{ESTABLISHMENT OF THE LOGIC SIMULATION MODEL}

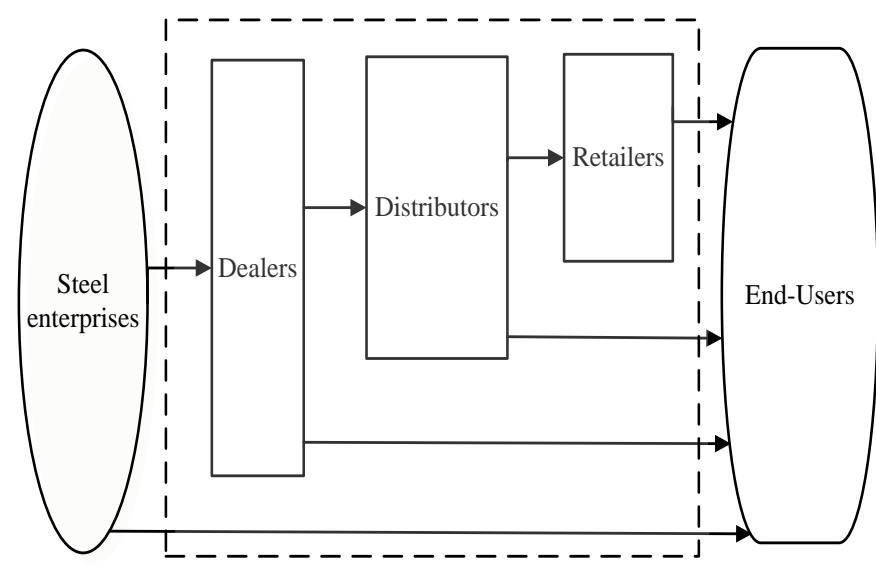

Figure 1. The logic simulation framework the mode- TSLS.

In the TSLS (Traditional Steel Logistics System), distribution links need to pass through the first level, two level and other levels of transit, From upstream to downstream to make a multi-level supply chain structure, customers need to change the way to purchase the steel products. 


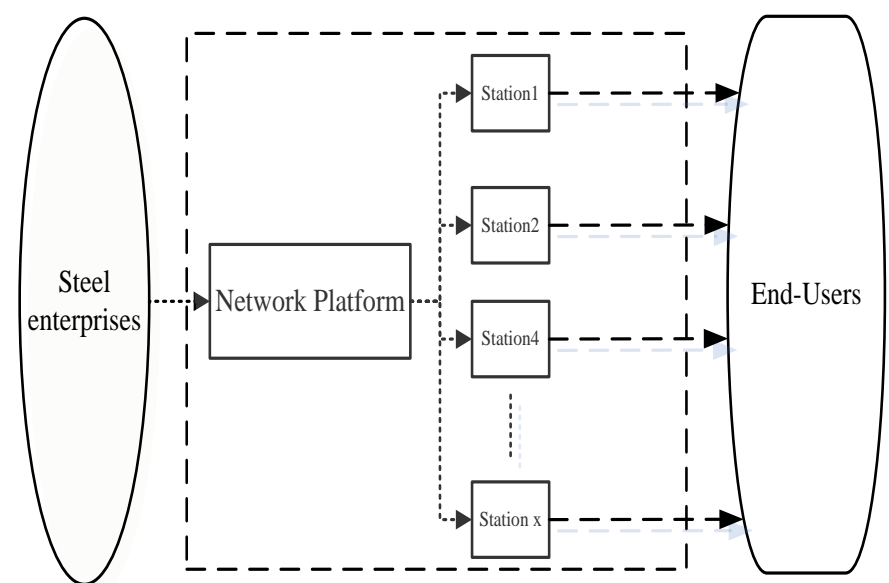

Figure 2. The logic simulation framework the mode- ESLS.

In the ESLS(E-commerce Steel Logistics System), customers follow the rules of the network flow, they can entry network logistics system of steel trading and services for 24 hours a day it can make the upper reaches of the steel enterprises to the end users to form a unified customer request, processing center, logistics system and after-sales service of the integrated structure [6].

\section{SIMULATION MODEL AND PARAMETER SETTING MODULE}

\section{A. Related Theories and Evaluation Indexes of the System}

The process of customer purchasing demand disposal to steel products follow the Frac (M / M/ S) Queuing System[7] $\mathrm{M}$ Entity reaches the system and follows the law of passion distribution process;

$\mathrm{N}$ - Service time follows the negative exponential distribution;

$\mathrm{S}$ - queuing rules of service counters follow the principle of first in first out.

Note: According to the formula, when the system is at stable state:

$$
\begin{aligned}
& p_{n}(s)=\left\{\begin{array}{l}
\frac{(s p)^{n} P_{0}(s)}{n !}, n \leq s \\
\frac{p^{n} s^{s}}{s !} P_{0}(s)=p^{n-s} p_{s}(s), n>s
\end{array}\right. \\
& p_{0}(s)=\frac{1}{\left[\sum_{n=0}^{s-1} \frac{(p s)^{n}}{n !}+\frac{(p s)^{s}}{s !}\left(\frac{1}{1-p}\right)\right]}
\end{aligned}
$$

$s-$ The number of the system servers;

$n-$ The number of the system customers;

$p_{n}(s)$ The transient distribution of the queue length;

$\rho-$ Service intensity of the queuing system;

If definite $\rho<1$, system is in steady state conditions.
Note: Using the methods of analytical calculation, several Measure indexes could be drawn from the results described above. The simulation used the following four commonly indicators of quality of service evaluation to measure the operation of the system, these four indicators are all generated by the simulation system.

$$
L_{q}=\sum_{k=s+1}^{\infty}(k-s) P_{n}(s)=\frac{(\rho s)^{s}}{(1-\rho)^{2} s !} p_{n}(s)
$$

$L_{q}$ The average length of the queue;

$$
L_{s}=L_{q}+\rho s
$$

$L_{s} \_$The average length of the team;

$$
W_{s}=\frac{L_{s}}{\lambda}
$$

$W_{s} \longrightarrow$ The average sojourn time;

$$
W_{q}=\frac{L_{q}}{\lambda}
$$

$W_{q}$ The average waiting time.

According to the queuing theory to calculate method and the steady-state performance metric, make the reasonable assignment to the process of system, and evaluate the effectiveness of the operation result of the whole system, receiving station service efficiency, the server busy degree and the utilization rate of resources, in order to test and evaluate advantages and disadvantages of operational capabilities and the actual results [8].

\section{B. Simulation Model design}

Assumptions:

- Two modes have the same personnel disposition and construction machinery;

- Building a perfectly systematic environment and checking that everything is still working;

- The process from the customers into the system to leave that means transaction is completed, it needn't consider the same customer repeatedly in and out the system; 
- Do not consider operating loss and empty rate of system server;

- Do not consider order cost and price volatility of steel products.

The simulation model of the mode -TSLS:

The mode -TSLS is composed of the top-level simulation model and the four sub-models. Follow the daily working hours of the steel enterprises, all kinds of resources can be used eight hours a day, set up the model five days a week, and users can access system and apply requirements 8-hours a day.

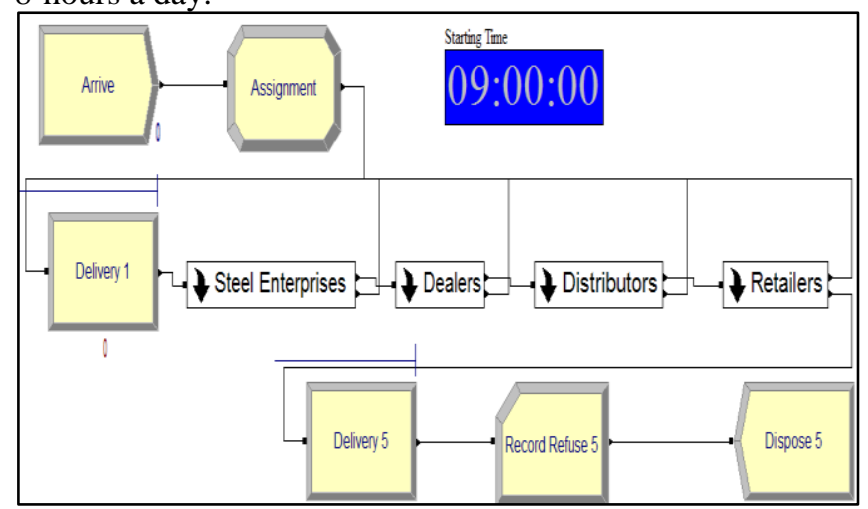

Figure 3. The simulation model of the mode -TSLS.

The simulation model of the mode-ESLS:

The mode -ESLS is composed of the six sub-models, follow the daily working hours of the working hours of ecommerce platform, all kinds of resources can be used 24 hours a day, set up the model seven days a week, and users can access system and apply requirements 24-hours a day.

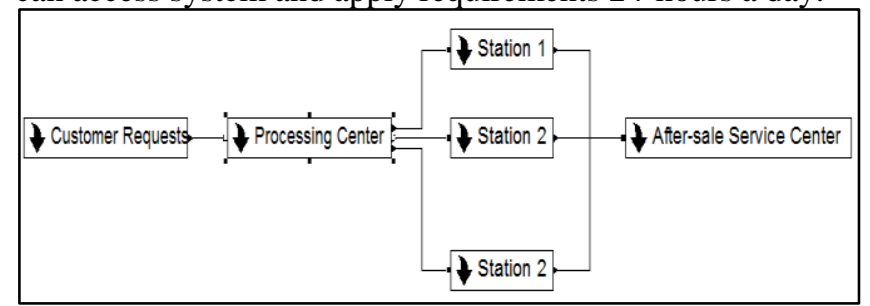

Figure 4. The simulation model of the mode -ESLS.

\section{Simulation Data Input}

TABLE I. CUSTOMER ARRIVAL LAW AND THE PARAMETER ASSIGNMENT OF SERVICE TIME OF MODE -TSLS

\begin{tabular}{|c|c|c|c|}
\hline $\begin{array}{c}\text { Module } \\
\text { name }\end{array}$ & Module function & $\begin{array}{c}\text { Definition } \\
\text { of function }\end{array}$ & Expression \\
\hline $\begin{array}{c}\text { Custome } \\
\text { r arrive }\end{array}$ & $\begin{array}{c}\text { Law of entity } \\
\text { arrival time }\end{array}$ & Exponential & $-0.001+\operatorname{EXPO}(5)$ \\
\hline $\begin{array}{c}\text { Arrival } \\
\text { time }\end{array}$ & $\begin{array}{c}\text { Customer arrival } \\
\text { time }\end{array}$ & Triangular & $\operatorname{TRIA}(1.5,3.5,5.52)$ \\
\hline $\begin{array}{c}\text { Delivery } \\
1,6\end{array}$ & $\begin{array}{c}\text { platform service } \\
\text { time }\end{array}$ & Triangular & $\operatorname{TRIA}(2,4,6)$ \\
\hline $\begin{array}{c}\text { Delivery } \\
2,3,4\end{array}$ & $\begin{array}{c}\text { Logistics delivery } \\
\text { time }\end{array}$ & Triangular & $\operatorname{TRIA}(1,3,5)$ \\
\hline
\end{tabular}

TABLE II. CUSTOMER ARRIVAL LAW AND THE PARAMETER ASSIGNMENT OF SERVICE TIME OF MODE -ESLS

\begin{tabular}{|c|c|c|c|}
\hline Module name & Module function & $\begin{array}{c}\text { Definition } \\
\text { of function }\end{array}$ & Expression \\
\hline Customer arrive & $\begin{array}{l}\text { Law of entity } \\
\text { arrival time }\end{array}$ & Exponential & $\begin{array}{c}0.001+\mathrm{EXPO}(5 \\
)\end{array}$ \\
\hline Arrival time & $\begin{array}{c}\text { Customer arrival } \\
\text { time }\end{array}$ & Triangular & $\begin{array}{c}\text { TRIA(1.5,3.5,5 } \\
.52) \\
\end{array}$ \\
\hline Choose goods & Buying time & Triangular & $\begin{array}{c}\text { TRIA( } 0.5,1,1.5 \\
)\end{array}$ \\
\hline Pay & Payment time & Uniform & $\begin{array}{c}\text { UNIFORM }(1,3 \\
, 1.8) \\
\end{array}$ \\
\hline Conform order & Confirmation time & Triangular & $\operatorname{TRIA}(1,3,5)$ \\
\hline Delivery & $\begin{array}{c}\text { Logistics delivery } \\
\text { time }\end{array}$ & Triangular & $\operatorname{TRIA}(2,4,6)$ \\
\hline Replenish & $\begin{array}{c}\text { Inventory } \\
\text { Transshipment } \\
\text { time }\end{array}$ & Triangular & $\operatorname{TRIA}(1,3,5)$ \\
\hline Handing & $\begin{array}{l}\text { after-sales service } \\
\text { time }\end{array}$ & Triangular & $\operatorname{TRIA}(1,3,5)$ \\
\hline
\end{tabular}

\section{Analysis of the Results of the Simulation Output}

We input the data into the Arena simulation software, it will automatically generate documents of txt and output all the statistics which set up in the model, it can get the results in the form of report, then sort and analyze those related statistics.

\begin{tabular}{lrrrr} 
Scheduled Utilization & Avesge & Half With & $\begin{array}{r}\text { Mirimum } \\
\text { Averge }\end{array}$ & $\begin{array}{r}\text { Maximum } \\
\text { Averge }\end{array}$ \\
\hline Resource 1 & 0.9739 & .05 & 0.8983 & 1.0000 \\
Resource 2 & 0.2219 & .08 & 0.1716 & 0.3353 \\
Resource 3 & 0.0951 & .04 & 0.03638718 & 0.1254 \\
Resource 4 & 0.06652490 & .05 & 0.00 & 0.1038
\end{tabular}

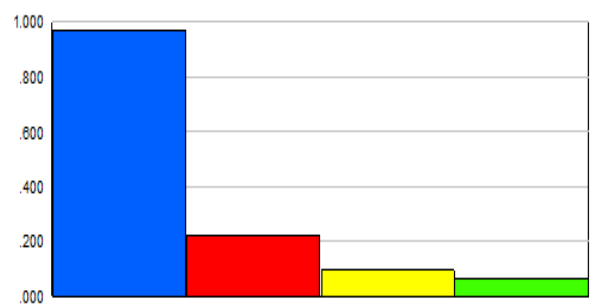

Figure 5. The average resource utilization of mode- TSLS.

\begin{tabular}{lrrrr} 
Scheduled Utilization & Average & Half Witth & $\begin{array}{r}\text { Minimum } \\
\text { Average }\end{array}$ & $\begin{array}{r}\text { Maximum } \\
\text { Average }\end{array}$ \\
\hline Resource 1 & 0.6580 & .17 & 0.5007 & 0.8724 \\
Resource 2 & 0.5581 & .13 & 0.4252 & 0.7138 \\
Resource 3 & 0.1249 & .06 & 0.04641785 & 0.1668 \\
Resource 4 & 0.3365 & .09 & 0.2646 & 0.4551
\end{tabular}

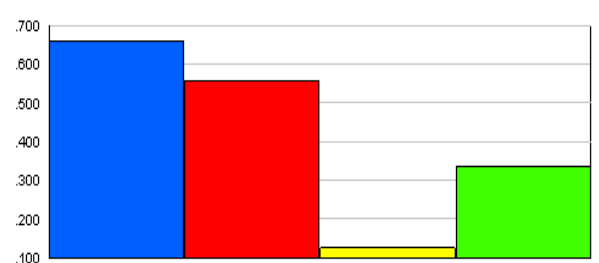

Figure 6. The average resource utilization of mode- ESLS. 
TABLE III. OUTPUT PERFORMANCE INDICATORS

\begin{tabular}{|c|c|c|}
\hline $\begin{array}{c}\text { Performance } \\
\text { indicators }\end{array}$ & $\begin{array}{c}\text { Mode- } \\
\text { TSLS }\end{array}$ & Mode- ISLS \\
\hline $\begin{array}{c}\text { The average waiting } \\
\text { time(hours) }\end{array}$ & 9.7181 & 4.4874 \\
\hline $\begin{array}{c}\text { The average sojourn } \\
\text { time(hours) }\end{array}$ & 17.265 & 13.499 \\
\hline WIP & 3.8848 & 3.0439 \\
\hline
\end{tabular}

By the results showed that: the average resource1 utilization of the mode- TSLS is $97.39 \%$, the processors are very busy, the system cannot perform effectively, but the average resource 4 utilization is just $6.65 \%$, the processors can not effectively use resources .By comparison, the modeESLS is more efficient than the mode- TSLS resources, and the level of service is efficient and the institutions setting is reasonable.

According to these output performance indicators of the average waiting time, the average sojourn time, and the WIP(the average of the queue length)the all kinds of performance indicators of mode- ESLS are better than the mode- TSLS. Therefore, the E-commerce steel logistics system has the practical rationality to improve the development of Chinese steel logistics.

\section{CONCLUSION}

The paper puts forward the planning method of steel logistics system under e-commerce environment, and compare the two kinds of logistics system between the traditional steel logistics and e-commerce Steel Logistics System. Establishing the logic simulation model, and use the Arena simulation software reflect the process of the logistics system veraciously, and then analyze the simulation result and give the conclusion and improving performance, though the research, we can find a scientific methods to put some suggestions for steel logistics and achieve the goals about the e-commerce steel logistics used in steel industries, and share those management methods to the steel enterprises. Finally, accelerating the development of e-commerce steel logistics system and solve the serious problems of Chinese steel industries.

\section{ACKNOWLEDGMENT}

This research was financially supported by the school of Management of Wuhan University of Science and Technology and Graduate Student Education Research Project of Wuhan University of Science and Technology.

\section{REFERENCES}

[1] W. David Kelton, Randall P. Sadowsky and David T. Sturrock, "Simulation with Arena," 3rd ed., New York: The McGraw-Hill Companies, 2004.

[2] XIE Jinxing, "Optimization modeling and LINDO/LINGO software,"(in Chinese) Beijing: Tsinghua University Press, 2005.

[3] LEI Dingyou, WANG Dong and LIIU Mingxiang, "Optimization Model and Algorithm of Utilization of Arrival and Departure Tracks in Railroad Passenger Station,"(in Chinese) Journal of Traffic and Transportation Engineering, vol. 7, pp. 84-87, October 2007.

[4] LI Jitao and FU Jia, "Microscopic Simulation Model and Analysis on Waiting Area of Large Scale Railway Passenger Station,"(in Chinese) Journal of Transportation Systems Engineering and Information Technology, vol. 11, pp. 44-49, February 2011.

[5] XU Yan, "Optimization of Application of the Waiting Hall of Railway Passenger Station,"(in Chinese) Railway Operation Technology, vol. 13, pp. 32-34, October 2007.

[6] YIN Hongjun and LUO Sai, "Study on Program Optimal Methods of Waiting Hall in Major Railway Passenger Station,"(in Chinese) Railway Computer Application, vol. 17, pp. 4-6, September 2008.

[7] James A. Fitzsimmons and Mona J. Fitzsimmons, (in Chinese) "Service management: operations, strategy and Information Technology, "Beijing: China Machine Press, 2003.

[8] Yinghui Tang and Xiaowo Tang. "Queuing Theory,"(in Chinese) Beijing: Science Press, 2006. 